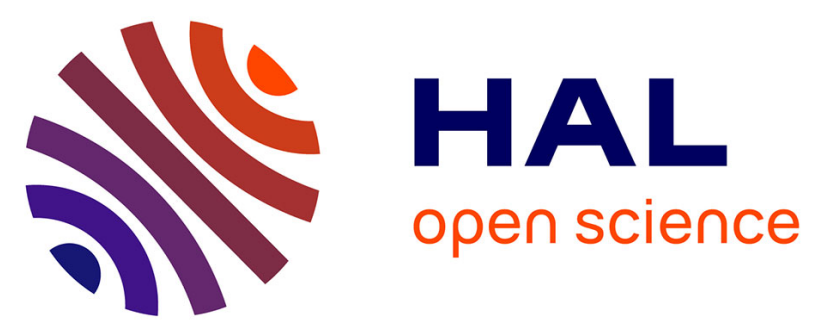

\title{
An efficient and inexpensive method for functionalizing metallic biomaterials used in orthopedic applications
}

Soria Hamdaoui, Ambroise Lambert, Hafit Khireddine, Rémy Agniel, Annelise

Cousture, Régis Coulon, Olivier Gallet, Séverine Alfonsi, Mathilde Hindié

\section{To cite this version:}

Soria Hamdaoui, Ambroise Lambert, Hafit Khireddine, Rémy Agniel, Annelise Cousture, et al.. An efficient and inexpensive method for functionalizing metallic biomaterials used in orthopedic applications. Colloid and Interface Science Communications, 2020, 37, pp.100282. 10.1016/j.colcom.2020.100282 . hal-02901831

\section{HAL Id: hal-02901831 \\ https://hal.science/hal-02901831}

Submitted on 17 Jul 2020

HAL is a multi-disciplinary open access archive for the deposit and dissemination of scientific research documents, whether they are published or not. The documents may come from teaching and research institutions in France or abroad, or from public or private research centers.
L'archive ouverte pluridisciplinaire HAL, est destinée au dépôt et à la diffusion de documents scientifiques de niveau recherche, publiés ou non, émanant des établissements d'enseignement et de recherche français ou étrangers, des laboratoires publics ou privés. 


\title{
An efficient and inexpensive method for functionalizing metallic biomaterials used in orthopedic applications
}

\author{
Soria Hamdaoui ${ }^{\mathrm{a}, \mathrm{b}}$, Ambroise Lambert $^{\mathrm{a}}$, Hafit Khireddine ${ }^{\mathrm{b}}$, Rémy Agniel ${ }^{\mathrm{a}}$, Annelise Cousture ${ }^{\mathrm{c}}$, \\ Régis Coulon $^{\mathrm{d}}$, Olivier Gallet ${ }^{\mathrm{a}}$, Séverine Alfonsi ${ }^{\mathrm{e}}$, Mathilde Hindié ${ }^{\mathrm{a}, *}$ \\ ${ }^{\text {a }}$ CY Cergy Paris Université, ERRMECe, F-95000 Cergy, France \\ ${ }^{\mathrm{b}}$ Laboratoire de Génie de l'Environnement, Faculté de Technologie, Université de Bejaia, 06000 Bejaia, Algeria \\ ${ }^{\mathrm{c}}$ CY Cergy Paris Université, L2MGC, F-95000 Cergy, France \\ ${ }^{\mathrm{d}}$ CMS -Boilermaking and Metalwork Company, 03470 Saligny sur Roudon, France \\ ${ }^{\text {e }}$ CY Cergy Paris Université, LPPI, F-95000 Cergy, France
}

A R T I C L E I N F O

\section{Keywords:}

316 L stainless steel

Polypyrrole

Electrodeposition

Biomaterials

Calcium phosphate

Steam sterilization

STRO- ${ }^{+}$A pre-osteoblasts

\begin{abstract}
A B S T R A C T
Implantations of metallic biomaterials are being carried out more and more frequently due to accident and population aging. Therefore, there is a need for new metallic implants which can combine properties such as durability, biocompatibility and affordability. In this study, multilayer functionalized 316 L stainless steel (SS) supports resistant to steam sterilization were presented. An electropolymerization of pyrrole was performed on SS supports to obtain a protective layer. This polypyrrole coating rendered SS surface resistant to corrosion. Then an electrodeposition of Calcium Phosphate (CaP) doped with increasing concentrations of silicon ( $\mathrm{Si}$ ) ranging from 0 to $2 \mathrm{mM}$ was tested to improve support bone integration. The impacts of silicon addition in the CaP coating without or after steam sterilization were analyzed by profilometry, Scanning Electron Microscopy and Fourier Transform Infrared Spectroscopy. These latter revealed that CaP doped with $0.5 \mathrm{mM}$ of Si constituted the optimal support formulation, presenting sterilization resistance and good biocompatibility.
\end{abstract}

\section{Introduction}

The implantation of orthopedic biomaterials is widely used all around the globe to restore physiological functions. Approximately $70 \%$ of the implants used in medicine are metallic biomaterials [1] and are mainly used to repair failed hard tissue. The demand for implants is increasing exponentially as part of the efforts to improve the life quality of the aging population. The global market for implants is expected to grow to $\$ 115.8$ billion by 2020 [2].

The three most implanted metallic biomaterials are titanium alloys, cobalt-chromium alloys and stainless steel (SS). The 316 L SS is the most widely used alloy mainly for non-permanent implants (e.g. bone plates, screws) and dental surgery [3,4]. Despite 316 L SS having good mechanical properties, good biocompatibility and being inexpensive, this alloy is less used for permanent implantation due to the corrosion induced by the contact with body fluids and the release of toxic ions such as nickel and chromium ions which causes local inflammation [5-7]. Among all the SS implants that failed, more than $90 \%$ presented corrosion attack [8]. Different physical and chemical techniques have been developed to improve SS resistance to corrosion such as plasma immersion ion implantation and deposition [9], surface modification of biomedical 316 L SS with zirconium carbonitride coatings [10], dip coating [11], electropolishing and acid dipping [12] or sol-gel spin coating [13]. In this study, the electrodeposition of an electro-conductive polymer was chosen to prevent SS corrosion. In the past decades steel surface passivation using conducting polymers such as polyaniline, polypyrrole, and polythiophene has been particularly studied and improved [14]. A conducting polymer coating on an implant prevents the release of harmful ions into the body. Furthermore, electrodeposition is useful in controlling the chemical composition and thickness of the coating as demonstrated by Martins et al. [15]. Depositions are reproductive even on complex geometry or porous supports and only inexpensive equipment is needed to perform electrodepositions [16,17].

The electro-conductive polymer retained for this study was polypyrrole (PPy) because of its high resistance to corrosion and delamination $[18,19]$, easy synthesis, high conductivity, good adhesion, and good biocompatibility [20]. PPy hydrophilicity can also be changed by electrochemical reductions and oxidations [21] that allow to modify PPy topography. However, the absence of PPy functional groups able to

\footnotetext{
* Corresponding author.

E-mail address: mathilde.hindie@u-cergy.fr (M. Hindié).
} 
interact with human body biomolecules blocks the further deposition of exogenous biological molecules such as, for instance, extracellular matrix glycoproteins [3]. A PPy coated implant is considered a passive biocompatible material since no adverse tissue response is observed at the implantation site [22]. Several approaches have recently been developed to improve the biocompatibility and biointegration of PPy by incorporating other materials such as hydroxyapatite nanoparticles or zinc oxide particles $[23,24]$. Chakraborty et al. have also developed a fast method to synthesize hydroxyapatite PPy composites by mixing calcium phosphate $(\mathrm{CaP})$ with Py solution before performing electrodeposition [25]. Another approach to functionalizing PPy coating is the deposition of a second porous layer of strontium hydroxyapatite [16]. This approach maintains hydroxyapatite porosity and the bilayer formed strongly adheres to $316 \mathrm{~L}$ SS. Hydroxyapatite direct coating on metallic supports has been developed by several researchers [26] but the corrosion resistance of hydroxyapatite could not improve in some cases [27].

Among numerous bioactive materials, osteoconductive $\mathrm{CaP}$ is conventionally employed in orthopedic surgery as a bone ceramic substituting material due to its biocompatibility, bioactivity and good adaptation under in vivo circumstances [28]. CaP is the main component of the inorganic bone matrix [29] and presents an inherent biocompatibility when it is applied as a biomaterial in the human body [30]. CaP coatings could significantly improve the biological performance of metallic implants [31] and could promote osteointegration [32]. When seeking to improve ceramic bioactivities, silicon ( $\mathrm{Si}$ ) is often used as a substituent or a dopant to improve the chemical structure, and the mechanical strength [33] and to enhance biomimetic bone matrix [34]. Moreover, silicon (Si), which is a key element in bone growth, is known to enhance and stimulate osteoblast activity [35]. Si has been found not only to promote osteoblast differentiation, but also to facilitate bone repair at the wounded site [36]. Previous studies have demonstrated promising effects of $\mathrm{Si}$ incorporation on the bioactivity of CaP supports [37].

Although implant strategies are largely well described, implant sterilization and resulting effects are nevertheless less studied in the literature even though they are essential to orthopedic surgery. Biomaterial associated infections are critical complications of modern orthopedic surgery, which often lead to prolonged patient pain [38]. The asepsis of functionalized biomaterial could constitute a real scientific and technological obstacle due to sterilization protocols that could damage the implant's chemical or physical properties. Different conventional biomaterial sterilization methods such as ethylene oxide, gamma irradiation or steam sterilization could be employed. Ethylene oxide sterilization is time consuming because the removal of all toxic residual ethylene oxide elimination requires a long time [39], whereas gamma ray sterilization is faster but could damage medical polymer devices [40] and imposes economic and technological constraints. Moreover, gamma ray sterilization could have deleterious effects on patient-care equipment such as delamination in hip prosthesis and cracking in polyethylene knee bearing [41]. Compared to plasma and ethylene oxide, steam sterilization could be an interesting alternative for large-scale sterilization. Thus, steam sterilization appears as the gold standard technique for sterilizing metal-based biomaterials and is widely used in hospitals and medical divisions [42]. Steam sterilization presents several advantages as it is nontoxic, inexpensive, bactericidal, has short treatment time and good penetration [43]. However, sterilization techniques cannot be used on temperature- or moisture-sensitive materials and numerous cycles of steam sterilization may damage SS implants, inducing corrosion [44]. A new sterilization approach has been recently developed based on supercritical carbon dioxide $\left(\mathrm{ScCO}_{2}\right)$. This technique is efficient on temperature-sensitive materials but, to date, no specific international standard protocol has been developed for using this procedure, whereas steam sterilization is a well-established method for sterilizing biomaterial (ISO 17665-1:2006 "Moist heat/ Steam sterilization method") [42].
The aim of this present work was to optimally functionalize $316 \mathrm{~L}$ SS supports at low cost, through successive electrodepositions of a PPy film and a coating of $\mathrm{CaP}$ doped with different Si concentrations. The multicomposite coatings formed onto substrates had to not be damaged by steam sterilization. To this end, the coatings' physico-chemical properties were characterized and the effects of sterilization were analyzed.

The response of the STRO-1 + A pre-osteoblasts cultured on our supports was studied so as to investigate the effect of Si doping on cell viability and morphology. The optimal $\mathrm{CaP}+\mathrm{Si}$ support synthesis protocol was thus determined and its biocompatibility was tested.

\section{Materials and methods}

\subsection{Materials}

Pyrrole (Py) (98\% purity) and sodium salicylate (99\% purity) were purchased from Alfa Aesar and Sigma-Aldrich respectively. The Py monomer was distilled at $50{ }^{\circ} \mathrm{C}$ under reduced pressure to obtain colorless purified Py solution.

The electrolytic solution for preparing the $\mathrm{CaP}+\mathrm{Si}$ coating was composed of calcium nitrate tetrahydrate $\left(\mathrm{Ca}\left(\mathrm{NO}_{3}\right)_{2} \cdot 4 \mathrm{H}_{2} \mathrm{O}, 98 \%\right.$ purity, Sigma-Aldrich), diammoniumhydrogen phosphate $\left(\left(\mathrm{NH}_{4}\right)_{2} \mathrm{HPO}_{4}, 99 \%\right.$ purity, Sigma-Aldrich) and sodium metasilicate nonahydrate $\left(\mathrm{Na}_{2} \mathrm{SiO}_{3} \cdot 9 \mathrm{H}_{2} \mathrm{O}, 98 \%\right.$ purity, Sigma-Aldrich).

\subsection{Electrochemical deposition}

\subsubsection{Steel plates preparation}

Medical grade 316 L SS plates were cut by means of blue laser technologies (CMS Saligny sur Roudon, France) using a L3030 laser cutting machine (TRUMPF, Germany) in order to obtain calibrated supports with a size of $30 \times 5 \times 2 \mathrm{~mm}$.

Before each electrochemical experiment, we polished the substrate with abrasive paper using different grain sizes $(120,220,360,400,600$, $800 \mathrm{Si}-\mathrm{C}$ ) and a Struers LaboPol-1 polisher. The supports were then cleaned in an ultrasonic bath using permuted water, ethanol and acetone in order to remove impurities. They were then air dried.

\subsubsection{PPy coating on 316 L SS}

The electrochemical polymerization of Py on the $316 \mathrm{~L}$ SS plates was performed using a potentiostat/galvanostat (VSP 150, Bio-Logic Science Instruments) combined with a three electrode system. The 316 L SS support was used as working electrode, a saturated calomel electrode (SCE) as reference, and a steel grid as counter-electrode. The electrolytic solution used contained $0.1 \mathrm{M}$ freshly distilled pyrrole and $0.5 \mathrm{M}$ salycilate sodium.

The applied potential was scanned between -0.5 and $1.1 \mathrm{~V} / \mathrm{SCE}$ for 15 cycles at a fixed scan rate of $50 \mathrm{mV} / \mathrm{s}$, and then rinsed with permuted water to remove unused monomer molecules prior to drying in the air.

\subsubsection{CaP coating on PPy coated 316 L SS}

$25 \mathrm{mM}$ calcium nitrate tetrahydrate $\mathrm{Ca}\left(\mathrm{NO}_{3}\right)_{2} \cdot 4 \mathrm{H}_{2} \mathrm{O}$ and $15 \mathrm{mM}$ ammonium phosphate dihydrogen $\mathrm{NH}_{4}\left(\mathrm{H}_{2} \mathrm{PO}_{4}\right)$ were dissolved in permuted water to prepare the electrolyte. The electrodeposition process was carried out at a speed of $20 \mathrm{mV} / \mathrm{S}$, a potential applied between -1.6 and $+1.1 \mathrm{~V} / \mathrm{SCE}$, and the electrolyte temperature set at $60{ }^{\circ} \mathrm{C}$.

\subsubsection{CaP + Si coating on PPy coated 316 L SS}

The $\mathrm{CaP}+\mathrm{Si}$ coating was prepared with a solution of $25 \mathrm{mM} \mathrm{Ca}$ $\left(\mathrm{NO}_{3}\right)_{2} \cdot 4 \mathrm{H}_{2} \mathrm{O} ; 15 \mathrm{mM} \mathrm{NH}{ }_{4}\left(\mathrm{H}_{2} \mathrm{PO}_{4}\right)$ and $0.3 ; 0.5 ; 1$ or $2 \mathrm{mM}$ $\mathrm{Na}_{2} \mathrm{SiO}_{3} \cdot 9 \mathrm{H}_{2} \mathrm{O}$ in permuted water. The same procedure used for $\mathrm{CaP}$ coatings was applied. 


\subsection{Surface characterization}

\subsubsection{Electrochemical corrosion testing}

The corrosion behavior of coatings on 316 L SS was evaluated via linear polarization in simulated body fluid (SBF) solution prepared according to the Kukobo et al. protocol [45]. The electrochemical studies were performed in a conventional three-electrode cell (a $316 \mathrm{~L} \mathrm{SS}$ support as working electrode, a reference electrode (SCE), and a steel grid as counter-electrode). Coated and uncoated samples were immersed in SBF for 30 min before each experiment. The $\mathrm{pH}$ of the electrolyte was maintained at 7.4. Potentiodynamic polarization studies were carried out at a scan rate of $5 \mathrm{mV} / \mathrm{s}$ in the potential range from -1 to $0.5 \mathrm{~V}$. The obtained data were recorded and each experiment was repeated at least three times to check reproducibility.

\subsubsection{Profilometric analysis}

The thickness and roughness of surface deposits were determined via profilometry (DEKTAK 150). The mean of three measurements calculated among five different areas on each support.

\subsubsection{Fourier transform infrared spectroscopy (FTIR-ATR)}

FTIR spectra were recorded from 4000 to $650 \mathrm{~cm}^{-1}$ on a Bruker Tensor 27 spectrophotometer equipped with PIKE Attenuated Total Reflectance (ATR). The spectra resulted from 16 scans with a $2 \mathrm{~cm}^{-1}$ resolution. Spectrometric analyses were performed at room temperature.

\subsection{Biological evaluation}

Samples were systematically steam sterilized for $15 \mathrm{~min}$ at $120^{\circ} \mathrm{C}$ in a Melatronic 23 autoclave before cell culture.

\subsubsection{Cell culture}

STRO- ${ }^{+}$A (STRO) osteoblast progenitor cells [26] were kindly provided by Dr. P. Marie (Inserm U1132, Paris Diderot University, France). They were cultured at $37{ }^{\circ} \mathrm{C}$ in Iscove's modified Dulbecco's medium (IMDM) (Sigma-Aldrich) containing 10\% $(v / \mathrm{v})$ fetal bovine serum (FBS), $2 \mathrm{mM}$ Glutamax $^{\circledR}$ (Invitrogen), 100 units/ml penicillin (Gibco) and $0.1 \mathrm{mg} / \mathrm{ml}$ streptomycin (Gibco). The culture was incubated at $37{ }^{\circ} \mathrm{C}$ in a humidified atmosphere of $5 \% \mathrm{CO}_{2}$ until preconfluence.

\subsubsection{Cell viability}

Pre-confluent STRO cells were treated with trypsin/EDTA, harvested by means of centrifugation, and the cell pellet was re-suspended in IMDM containing $10 \%$ fetal calf serum (FCS) and $1 \%$ Glutamax $^{\circledast}$. The cell suspension was adjusted to $1 \times 10^{6}$ cells $/ \mathrm{ml}$. $60 \mu \mathrm{l}$ of cell suspension was seeding on each support. Culture was performed for 1 , 3 , or 8 days in a humidified atmosphere of $5 \% \mathrm{CO}_{2}$, at $37{ }^{\circ} \mathrm{C}$.

Viability tests were performed by staining cells with $4 \mu \mathrm{M}$ calcein $\mathrm{AM}$ and $1 \mu \mathrm{M}$ ethidium homodimer (LIVE/DEAD ${ }^{\circledR}$ kit for mammalian cells (Invitrogen) for $40 \mathrm{~min}$ at room temperature (RT). Cellularized supports were examined using a Leica fluorescence microscope $(10 \times$ objective). Living and dead cells were stained respectively with calcein $\mathrm{AM}$ and ethidium bromide dimer.

Images of cells were processed using the Image ${ }^{\circledR}$ software and then analyzed using the MATLAB ${ }^{\circledR}$ software. Measurements of cell viability were done on three independent fields per sample; they were renewed in two independent experiments in duplicate.

\subsubsection{Cell morphology}

To determine cell morphology, previously cellularized supports were fixed for $15 \mathrm{~min}$ with $4 \%$ paraformaldehyde solution in phosphate buffered saline (PBS). Non-specific binding sites were blocked by incubating the cells in PBS containing $1 \%$ bovine serum albumin (BSA) (Sigma-Aldrich) for $30 \mathrm{~min}$ at room temperature. Then cells were labeled for 45 min with a solution containing 4',6-diamidino-2-phenylindole dihydrochloride (DAPI) $(1 \mu \mathrm{g} / \mathrm{ml}-1)$ and phalloidin Alexa ${ }^{\circledR}$ $532(0.02 \mathrm{U} / \mathrm{ml})$ (Invitrogen). Observations and image capture were performed using a Confocal Laser Scanning Microscope (CLSM, Zeiss LSM 710) with adapted Plan-Apochromatic objectives $(\times 63)$. For each sample 3 independent fields were analyzed. Data are representative of two different experiments performed in duplicate.

\section{Results and discussion}

\subsection{Support functionalization and characterization}

\subsubsection{Electrochemical deposition of PPy coatings}

A black uniform smooth and adherent film of PPy was obtained on 316 L SS supports after applying the potential between -0.5 and $+1.1 \mathrm{~V} /$ ECS with a scanning speed of $50 \mathrm{mV} / \mathrm{s}$ for 15 cycles. In order to analyze the film formed on the supports, an SEM study was performed.

\subsubsection{Scanning electron microscopy (SEM) analysis}

The surface of an uncoated $316 \mathrm{~L}$ stainless steel support was homogeneous, with only small grooves due to polishing being observed (Fig. 1). The PPy film produced via cyclic voltammetry adhered to and uniformly covered the support. All the films formed were homogeneous and presented globular structures. Similar structures with numerous globules were observed by Martins et al. [15]. Furthermore, steam sterilization did not affect this film structure; the same film organization with globules was observed.

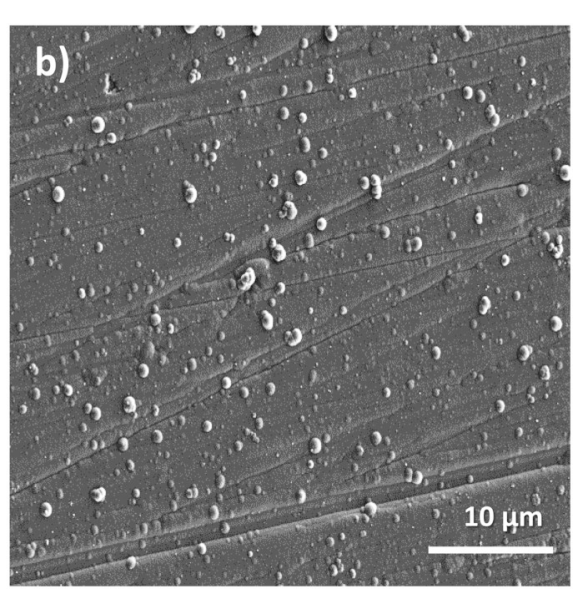

Fig. 1. SEM images of PPy electrodeposited 316 L SS supports. PPy before steam sterilization (a), and PPy after steam sterilization (b). 


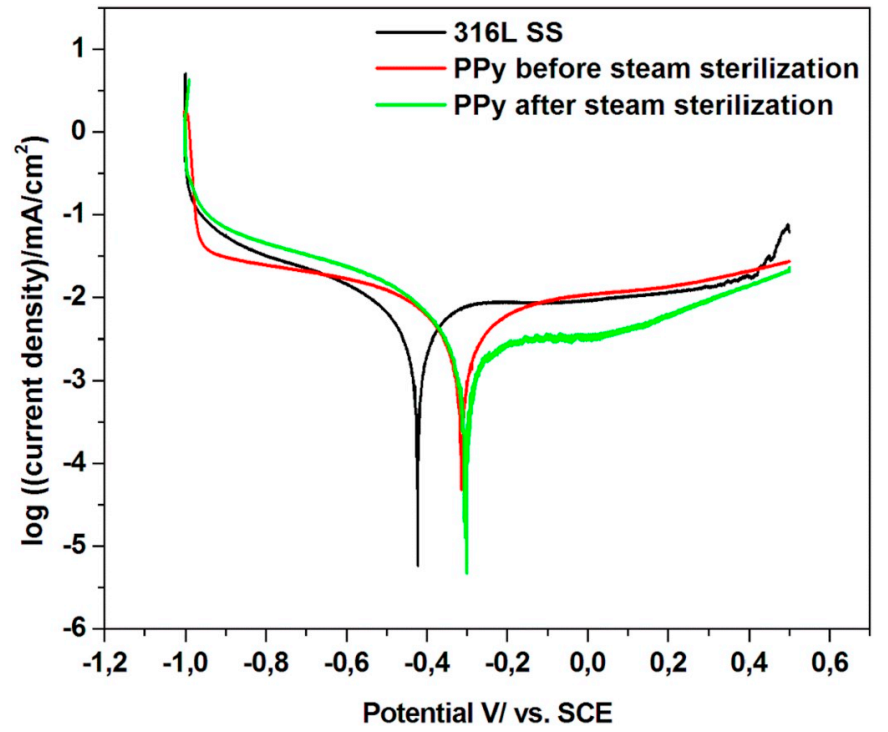

Fig. 2. Tafel polarization curves of $316 \mathrm{~L}$ SS supports coated or not coated with PPy, before and after autoclaving.

\subsubsection{Corrosion tests and topography analysis}

In order to evaluate the anticorrosion efficiency of PPy films, corrosion tests were carried out in an SBF medium. Fig. 2 shows the potentiodynamic polarization curves of the $316 \mathrm{~L}$ SS uncoated and coated with PPy, before and after steam sterilization. The Tafel extrapolations consisted of cathodic and anodic polarization used to evaluate the corrosion potential $\left(\mathrm{E}_{\text {corr }}\right)$ and the corrosion current density $\left(\mathrm{J}_{\text {corr }}\right)$. Results are presented in Table 1.

Potentiodynamic polarization curves manifested that the corrosion potential increased from -423 to $-313 \mathrm{mV}$ after PPy deposition on 316 L SS. This increase in the corrosion potential indicates that 316 L SS coated with PPy has a better anti-corrosion performance in SBF. It can be attributed to the formation of a passive film under the PPy layer due to the presence of sodium salicylate as already demonstrated by Ananth et al. [46]. In addition, the formation of a protective layer on the surface of $316 \mathrm{~L}$ stainless steel induces superior corrosion protection [47].

After steam sterilization, no significant change in the polarization parameters was observed, which demonstrates comparable resistance to corrosion (Table 1).

In parallel, the thickness and roughness of the PPy coating was measured. The PPy films formed via polymerization of Py were $2.2+/$ $-0.3 \mu \mathrm{m}$ thick which is comparable to the values obtained for the steam sterilized films (Table 1). Similar results were observed concerning PPy support roughness with sterile and unsterile PPy films.

\subsubsection{Calcium phosphate (CaP) deposition on PPy coated films}

To improve the osteointegration of our support, a second layer of calcium phosphate (CaP) was electrodeposited on PPy films. In parallel, silicon ( $\mathrm{Si}$ ) was added to the CaP mix to test the effect of the silicon when incorporated into the CaP layer on $316 \mathrm{~L}$ SS supports coated with PPy. This deposition was also performed via cyclic voltammetry. Previous studies were tested to select the best method to deposit a dual layer on $316 \mathrm{~L}$ substrates. Pulse electrodeposition was not efficient enough to promote $\mathrm{CaP}$ deposition onto PPy coated substrates. Sequential electrodepositions of PPy and CaP proposed in the present study appear to be the best method for getting a homogenous and adherent layer of CaP. Similar results were observed with the dual deposition of strontium hydroxyapatite onto PPy films which avoids coating cracking $[16,25]$. Each PPy coated support was immersed in the electrolyte solution prepared by mixing $25 \mathrm{mM}$ of calcium nitrate tetrahydrate $\mathrm{Ca}\left(\mathrm{NO}_{3}\right)_{2} \cdot 4 \mathrm{H}_{2} \mathrm{O}, 15 \mathrm{mM}$ of ammonium phosphate dihydrogen $\left(\left(\mathrm{NH}_{4}\right) \mathrm{H}_{2} \mathrm{PO}_{4}\right)$ in permuted water and supplemented with a respectively increasing amount of $\mathrm{Na}_{2} \mathrm{SiO}_{3} .9 \mathrm{H}_{2} \mathrm{O}$ from $0 ; 0.3 ; 0.5 ; 1$ to $2 \mathrm{mM}$. The electrodeposition was carried out at a speed of $20 \mathrm{mV} / \mathrm{s}$, and a potential applied between -1.6 and $1.1 \mathrm{~V} / \mathrm{SCE}$, while the electrolyte solution was also maintained at $60{ }^{\circ} \mathrm{C}$ during the deposition.

The supports obtained were characterized using profilometry, SEM and Fourier Transform Infrared Spectroscopy (FTIR). Preliminary measurements of the thickness and roughness of the $\mathrm{CaP}+\mathrm{Si}$ supports (data not shown) allowed us to select the most appropriate concentrations of $\mathrm{Si}$; among five $\mathrm{Si}$ concentrations tested ranging from 0 to $2 \mathrm{mM}$, only $0.5 \mathrm{mM}$ and $2 \mathrm{mM}$ Si were retained for further experiments. Those results were confirmed by SEM observations of each sample on which thickness and roughness were measured. The sample retained presented less of a blade- and needle-like morphology compared to the other ones. Those supports seemed to be the most favorable for osteoblast culture according to Mokabber et al. [48].

\subsection{Characterization of multi-coated supports}

\subsubsection{Support surface analysis}

The supports' properties before and after sterilization were compared, with neither $\mathrm{CaP}$ coatings nor $\mathrm{CaP}+\mathrm{Si}$ coatings being detached from 316 L SS supports by the effect of steam sterilization. Then the thickness and roughness of $\mathrm{CaP}$ and $\mathrm{CaP}+\mathrm{Si}$ coatings were measured. No significant differences were observed before or after sterilization, in neither the thickness nor the roughness of the coating (Fig. 3). However, changes in the coating thickness depending on the Si concentration added were noticed (Fig. 3a). The addition of $0.5 \mathrm{mM}$ of Si in electrodeposition solution induced the most important increase in coating thickness. The $\mathrm{CaP}+0.5 \mathrm{Si}$ coating reached a maximum thickness of $36 \pm 1 \mu \mathrm{m}$ (before sterilization) and $36.8 \pm 0.6 \mu \mathrm{m}$ (after sterilization). A similar increase in coating roughness was observed with the $0.5 \mathrm{mM}$ Si formulation (Fig. 3b). Beyond this, the Si concentration coating thickness and coating roughness decreased. So those results confirmed that $0.5 \mathrm{mM} \mathrm{Si}$ appears as the optimal concentration for performing $\mathrm{CaP}+\mathrm{Si}$ coatings. Analyses of materials' surfaces using profilometry helped to distinguish microscale changes in their topography. The supports' surface did not seem to have been altered by steam sterilization. To determine if steam sterilization induced lower scale changes in our samples' surface, SEM observations were performed.

\subsubsection{Surface morphology characterization via SEM}

The surface morphology of the $\mathrm{CaP}$ coating with a growing amount of $\mathrm{Si}$ incorporated is shown in Fig. 4. Before sterilization, both the CaP and $\mathrm{CaP}+2 \mathrm{mM} \mathrm{Si}$ coatings were composed of small shaped needles and thin elongated plates; whereas $\mathrm{CaP}+0.5 \mathrm{mM}$ Si supports presented

Table 1

Polarization and topography parameters of 316 L SS supports coated or not coated with PPy, before and after autoclaving.

\begin{tabular}{|c|c|c|c|c|}
\hline \multirow[t]{2}{*}{ Sample conditions } & \multicolumn{2}{|c|}{ Polarization parameter } & \multicolumn{2}{|c|}{ Topography parameter } \\
\hline & $\mathrm{E}_{\text {corr }}(\mathrm{mV}$ vs. SCE) & $J_{\text {corr }}\left(\mu \mathrm{A} \cdot \mathrm{cm}^{-2}\right)$ & Thickness $(\mu \mathrm{m})$ & Roughness $(\mu \mathrm{m})$ \\
\hline 316 L SS & -423 & 4.51 & / & $0.81 \pm 0.07$ \\
\hline 316 L SS + PPy & -313 & 3.51 & $2.20 \pm 0.30$ & $0.20 \pm 0.01$ \\
\hline 316 L SS + PPy + steam sterilization & -301 & 2.13 & $2.34 \pm 0.17$ & $0.22 \pm 0.03$ \\
\hline
\end{tabular}



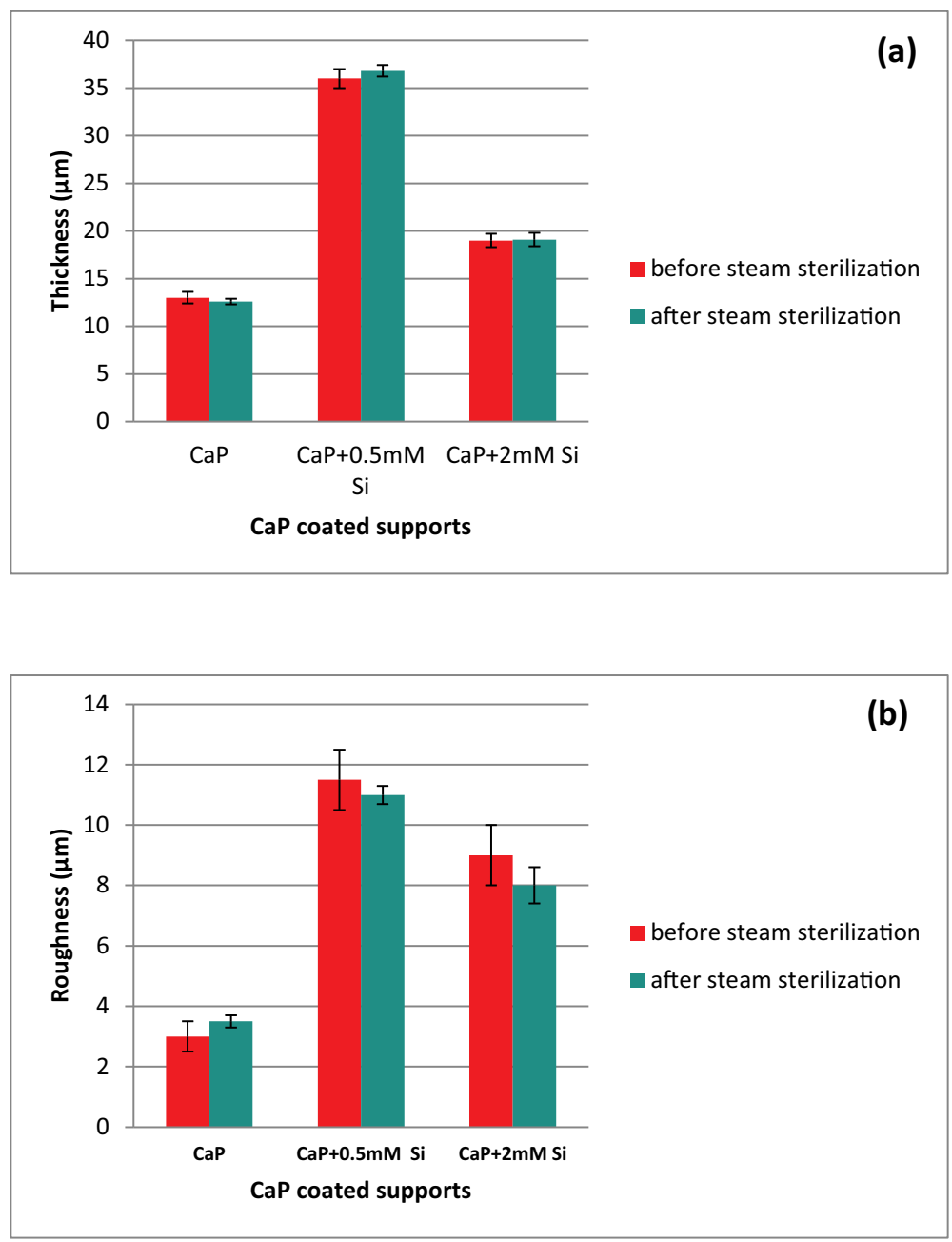

Fig. 3. Profilometry measurement of sample surface thickness (a) and roughness (b). CaP coatings were prepared with either 0.5 or $2 \mathrm{mM}$ of Si added to the deposit. Data are represented by mean \pm standard deviation ( $n=3$ independent measurements).

a mixture of round shaped crystals of different sizes with a more compact organization. Previous studies have demonstrated that CaP surface morphology has an important effect on cell attachment, proliferation and viability [49]. Because needlelike shape morphology could damage the cell's membrane and subsequent viability [48], CaP $+0.5 \mathrm{mM}$ Si supports presenting reduced needlelike morphology appeared to be the most favorable for osteoblast culture. The sub-micron topography observed in $\mathrm{CaP}+0.5 \mathrm{mM}$ Si supports is consistent with the study by Da Silva et al. who described a nanotopography induced by the incorporation of $\mathrm{Si}$ in hydroxyapatite tablets. Such a topography stimulates osteoblastic adhesion through the formation of numerous focal adhesion points [50] and stimulates osteogenic differentiation [51]. The supports' topography after steam sterilization was then analyzed. The blade structure of $\mathrm{CaP}$ supports was reduced after sterilization, while the $\mathrm{CaP}+2 \mathrm{mM} \mathrm{Si}$ support topography remained unchanged. Furthermore, sterilized $\mathrm{CaP}+0.5 \mathrm{mM}$ Si coated supports had denser, organized structure close to the bone surface [52]. Previous studies by Li et al. [53] demonstrated that steam sterilization could modify the nanoscale structure of $\mathrm{CaP}$ through the reduction of crystal boundaries. Cavities were still present through a globular organization of $\mathrm{CaP}$ $+0.5 \mathrm{mM}$ Si which appeared closer to the bone matrix organization (Fig. 4d) observed on bone implants after bone healing [54]. Such a topography could be more favorable for cell attachment and proliferation [55]. of $\mathrm{CaP}$ and $\mathrm{CaP}$ integrating an increasing quantity of $\mathrm{Si}$ were analyzed via FTIR. Spectra of sterilized substrates were compared to unsterile ones (Fig. 5). The band detected at $3572 \mathrm{~cm}^{-1}$ corresponded to the stretching vibrations of the hydroxyl group $(\mathrm{OH})$ (Fig. 5). Moreover, the band centered at $1648 \mathrm{~cm}^{-1}$ is characteristic to the bending mode of $\mathrm{H}_{2} \mathrm{O}$. The bands detected at $1121 \mathrm{~cm}^{-1}, 1075 \mathrm{~cm}^{-1}, 1036 \mathrm{~cm}^{-1}$ and $1021 \mathrm{~cm}^{-1}$ were associated with the $v_{3}$ vibration mode of O-P-O, the band at $961 \mathrm{~cm}^{-1}$ corresponded to the stretch vibration mode of O-P-O and the band $961 \mathrm{~cm}^{-1}$ corresponding to the $\mathrm{P}-\mathrm{O}$ stretching vibration mode $v_{1}[49,56,57]$. An increase in the intensity of the $869 \mathrm{~cm}^{-1}$ band was produced by the vibration mode $\mathrm{v}_{2}$ of the carbonate group $\left(\mathrm{CO}_{3}{ }^{2-}\right)$ $[34,58]$ induced by the incorporation of $\mathrm{Si}$ in the coating. This band was detected in all the coatings, probably due to the absorption of $\mathrm{CO}_{2}$ from the air. A new absorption band was detected at $790 \mathrm{~cm}^{-1}$ in the CaP $+\mathrm{Si}$ supports. This low intensity band observed corresponds to the elongation vibrations of the Si-O-Si bond which was observed in a previous study [59]. No significant spectra modifications were detected on sterilized supports the FTIR-ATR analysis, the same transmission bands with a decrease in the intensity of the $\mathrm{O}-\mathrm{H}$ and $\mathrm{H}-\mathrm{O}-\mathrm{H}$ bands were observed. FTIR-ATR spectra confirmed that autoclaving didn't modify support functional groups and the presence of $\mathrm{CaP}+\mathrm{Si}$ onto PPy coated substrates. 
Before steam sterilization
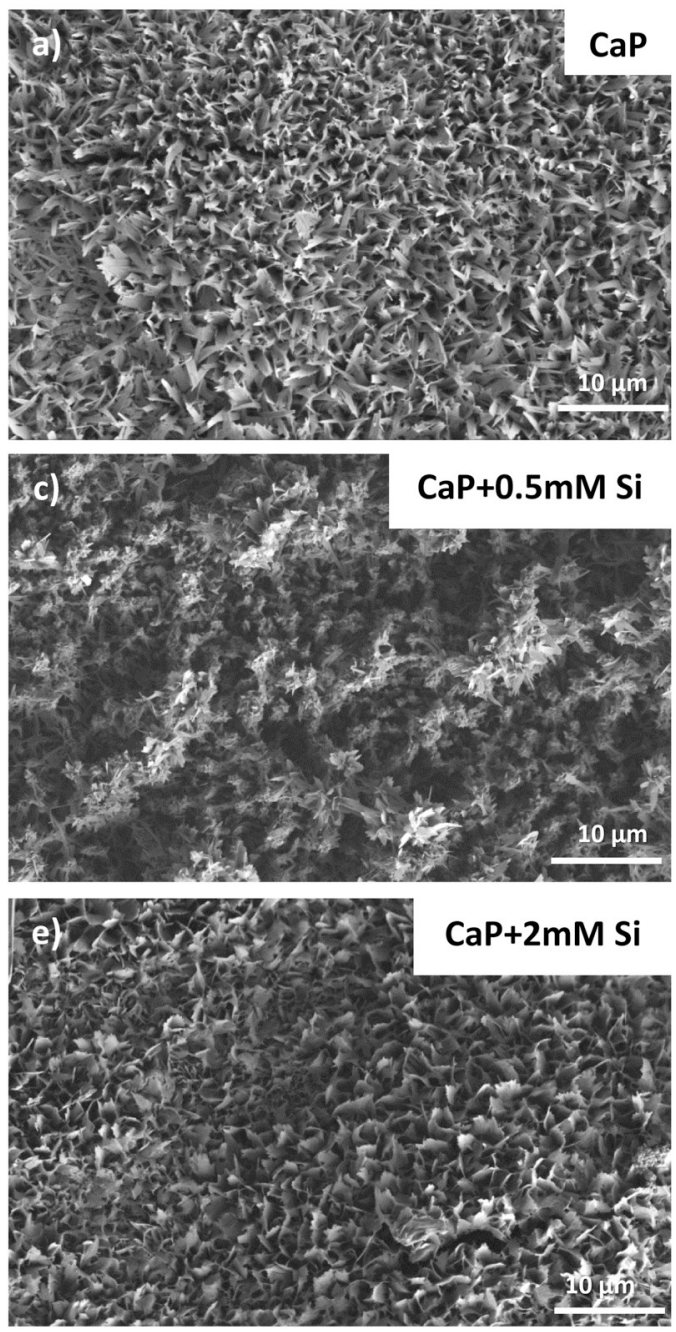

After steam sterilization
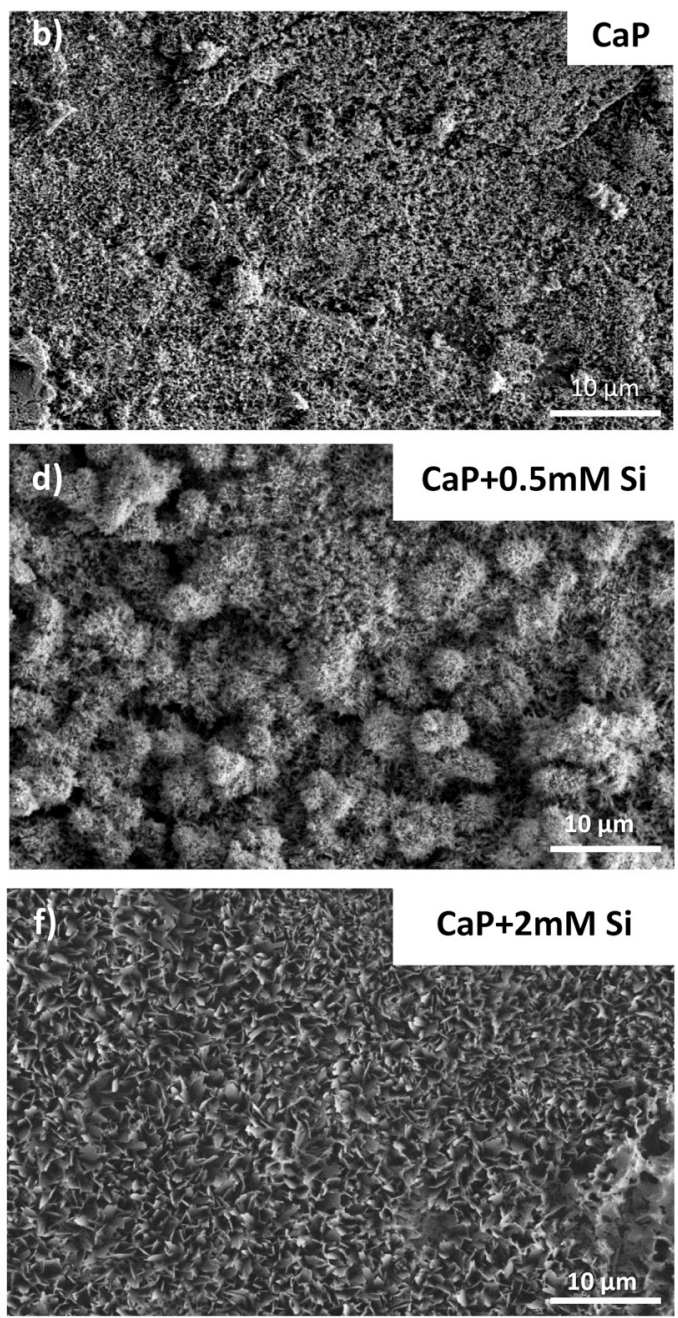

Fig. 4. SEM images of Cap + Si electrodeposited on PPy coated 316 L SS supports. Formulations presented are CaP before steam sterilization (a) and after steam sterilization (b), $\mathrm{CaP}+0.5 \mathrm{mM} \mathrm{Si}$ before steam sterilization (c) and after steam sterilization, (d) CaP $+2 \mathrm{mM}$ Si before steam sterilization (e) and after steam sterilization (f).
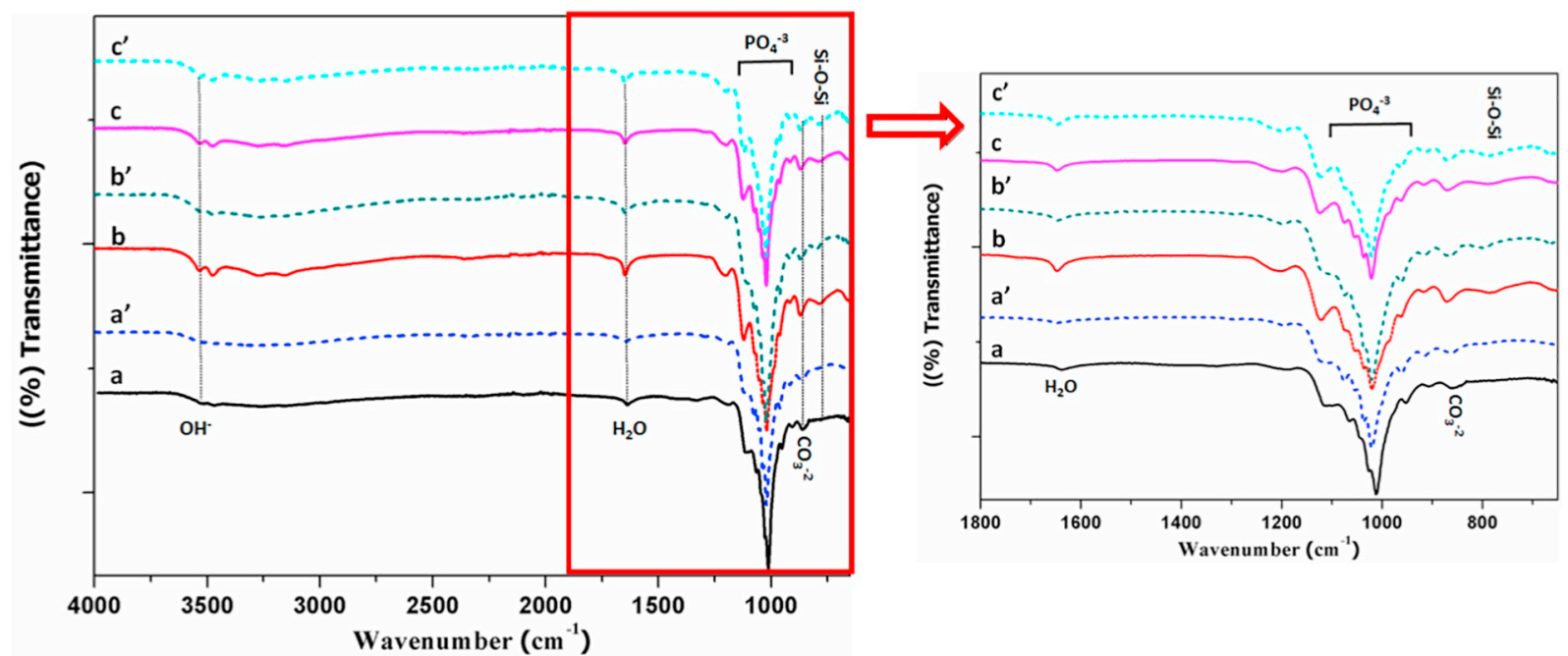

Fig. 5. FTIR-ATR spectra of $\mathrm{CaP}$ and $\mathrm{CaP}+\mathrm{Si}$ coating deposited on PPy. Spectra of CaP before steam sterilization (a) and after steam sterilization (a'), CaP $+0.5 \mathrm{mM} \mathrm{Si}$ before steam sterilization (b) and after steam sterilization (b'), CaP $+2 \mathrm{mM}$ Si before steam sterilization (c) and after steam sterilization (c'). 

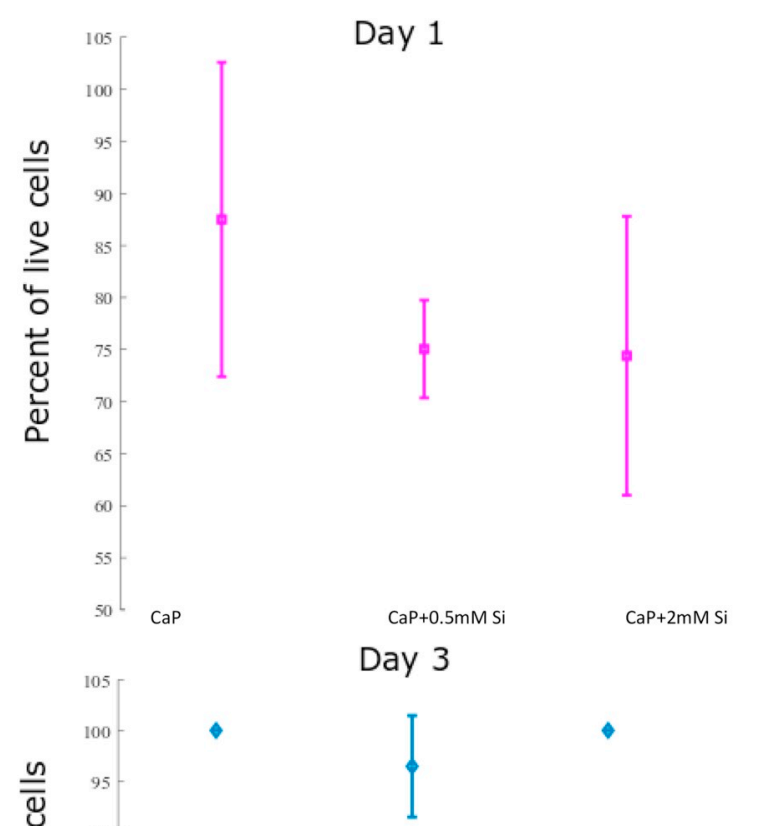

$\mathrm{CaP}$

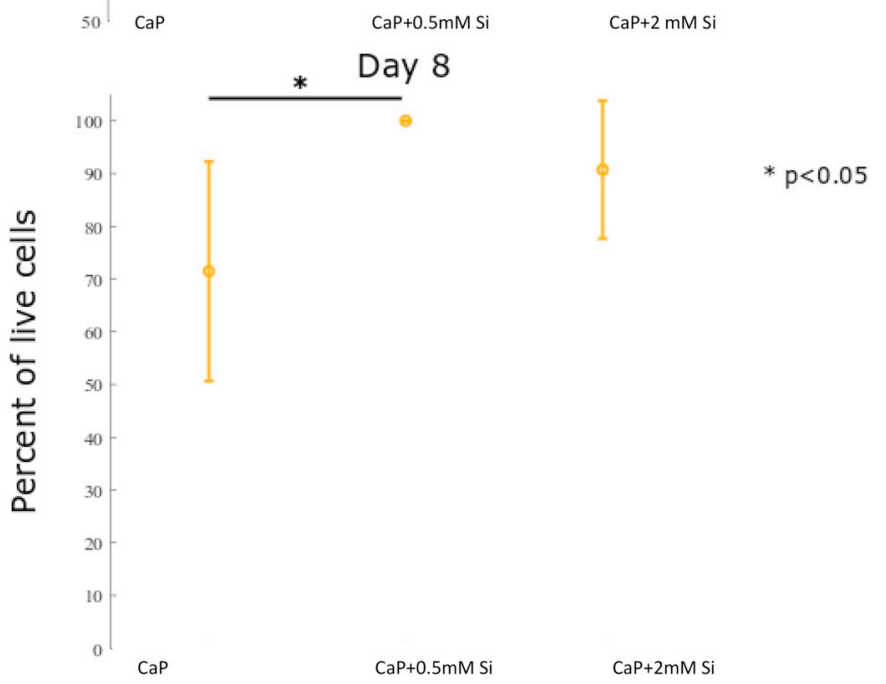

Fig. 6. Cell viability of STRO-1 + A cells stained using the LIVE/DEAD ${ }^{\circledR}$ viability kit. Cells were grown on $\mathrm{CaP}, \mathrm{CaP}+0.5 \mathrm{mM} \mathrm{Si}$ or $\mathrm{CaP}+2 \mathrm{mM}$ Si coating for 1,3 and 8 days. Data are expressed as percent of live cells and are represented by the mean \pm standard deviation ( $n=2$ experiments). Mood statistical test was done, ${ }^{*} P<0.05$.

\subsection{Effects of multilayer supports on pre-osteoblast behavior}

\subsubsection{Cell viability}

STRO- $1^{+}$A pre-osteoblasts were cultured on functionalized supports for 1, 3 and 8 days respectively. Cell viability was measured after staining adherent cells on supports using a Live/Dead ${ }^{\circledR}$ kit. Images of stained pre-osteoblasts observed with a fluorescence microscope were taken. The processing of photos via the Matlab $^{\circledR}$ software made it possible to calculate cell viability on each support type. As shown in Fig. 6, pre-osteoblast viability grew all along when culture was done on $\mathrm{CaP}+\mathrm{Si}$ supports, whereas a decrease in cell viability was noticed at day 8 on CaP supports. Cell viability was significantly higher on $\mathrm{CaP}$ $+0.5 \mathrm{mM}$ Si supports. The increase in cell mortality for pre-osteoblasts cultured for 8 days may be due to the saturation of the support surface saturation with cells (data not shown).

The percentage of live cells was equal to or greater than $75 \%$ for all supports, demonstrating their biocompatibility. Comparable osteoblast viability was described on stainless steel supports covered with PPy and hydroxyapatite $[25,46]$. The addition of $0.5 \mathrm{mM}$ Si enhanced viability as compared to other coatings. Pre-osteoblasts cultured on $\mathrm{CaP}$ $+0.5 \mathrm{mM} \mathrm{Si}$ supports for 3 and 8 days presented a viability of $95 \%$. These results are consistent with the positive cellular effect of the addition of $S i$ into phosphocalcic supports $[60,61]$.

Hence, our results confirm that $\mathrm{CaP}+0.5 \mathrm{Si}$ is the optimal support for pre-osteoblast culture.

\subsubsection{Cell morphology}

In parallel, the morphology of pre-osteoblasts was observed via confocal laser scanning microscopy (CLSM). Cells were cultured as described previously, before being fixed. Nuclei and actin filaments were stained with DAPI (cyan) and Alexa Fluor ${ }^{\circledR} 532$ phalloidin (magenta) respectively. Pre-osteoblast CSLM images are shown in Fig. 7: at day 1 the cells were mainly spread on both $\mathrm{CaP}+\mathrm{Si}$ supports and had a clearly distinguishable actin cytoskeleton (Fig. $7 \mathrm{~b}$ and c). Cells attached onto all types of supports at day 1 but the typical aspect of the osteoblasts' morphology [62] was observed mostly on supports coated with CaP 0.5 mM Si. The presence of pseudopodes in cells cultured on such supports confirmed their adhesion improvement. These results are consistent with previous studies demonstrating a stimulation of osteoblast spreading and adhesion induced by the substrates' nanotopography [34].

Then a significant increase in the number of cells was observed in time, for all the supports. Pre-osteoblasts spread more after day 3 and proliferated up to confluency at day 8 (Fig. 7). A previous study showed that osteoblasts cultured on silicon-substituted hydroxyapatite tablets presented more focal adhesion points and the osteoblast area increased in the presence of silicon. [50] Our results corroborate such data as preosteoblasts appeared connected to each other on $\mathrm{CaP}+0.5 \mathrm{~m} \mathrm{Si}$. STRO$1+$ A were much more elongated and presented spindle shaped morphology with an oriented cytoskeleton (Fig. 7h).

The increase in cell proliferation and spreading on both $\mathrm{CaP}$ $+0.5 \mathrm{mM}$ Si supports are in agreement with previous studies reporting the effect of Si on osteoblast growth $[61,63,64]$. We hypothesize that the nanotopography of $\mathrm{CaP}+0.5 \mathrm{mM} \mathrm{Si}$ supports together with the chemical presence of silicon synergize not only pre-osteoblast adhesion but also proliferation. Hence the $\mathrm{CaP}+0.5 \mathrm{mM} \mathrm{Si}$ support was the optimal support for cell culture and presented the best cytocompatibility.

\section{Conclusion}

The PPy deposition performed significantly protected 316 L SS against corrosion and this coating was steam sterilization resistant. CaP + Si coatings with increasing amount of Si were successfully performed on 316 L SS supports via cyclic voltammetry electrodeposition. SEM analysis showed that the morphology of the CaP coatings was modified by the $\mathrm{Si}$ concentration in the electrolyte. A $0.5 \mathrm{mM} \mathrm{Si}$ concentration induced substrate topography similar to the bone mineral matrix.

Crucially none of the CaP coatings was damaged by steam sterilization, indeed, this even improved the $\mathrm{CaP}+0.5 \mathrm{mM}$ Si topography which presented close to bone tissue morphology. FTIR-ATR analysis of the substrates confirmed that spectra were not modified by sterilization and the appearance of a new band related to the incorporation of a silicate group in the $\mathrm{CaP}$ structure was maintained. $\mathrm{CaP}+0.5 \mathrm{mM} \mathrm{Si}$ 

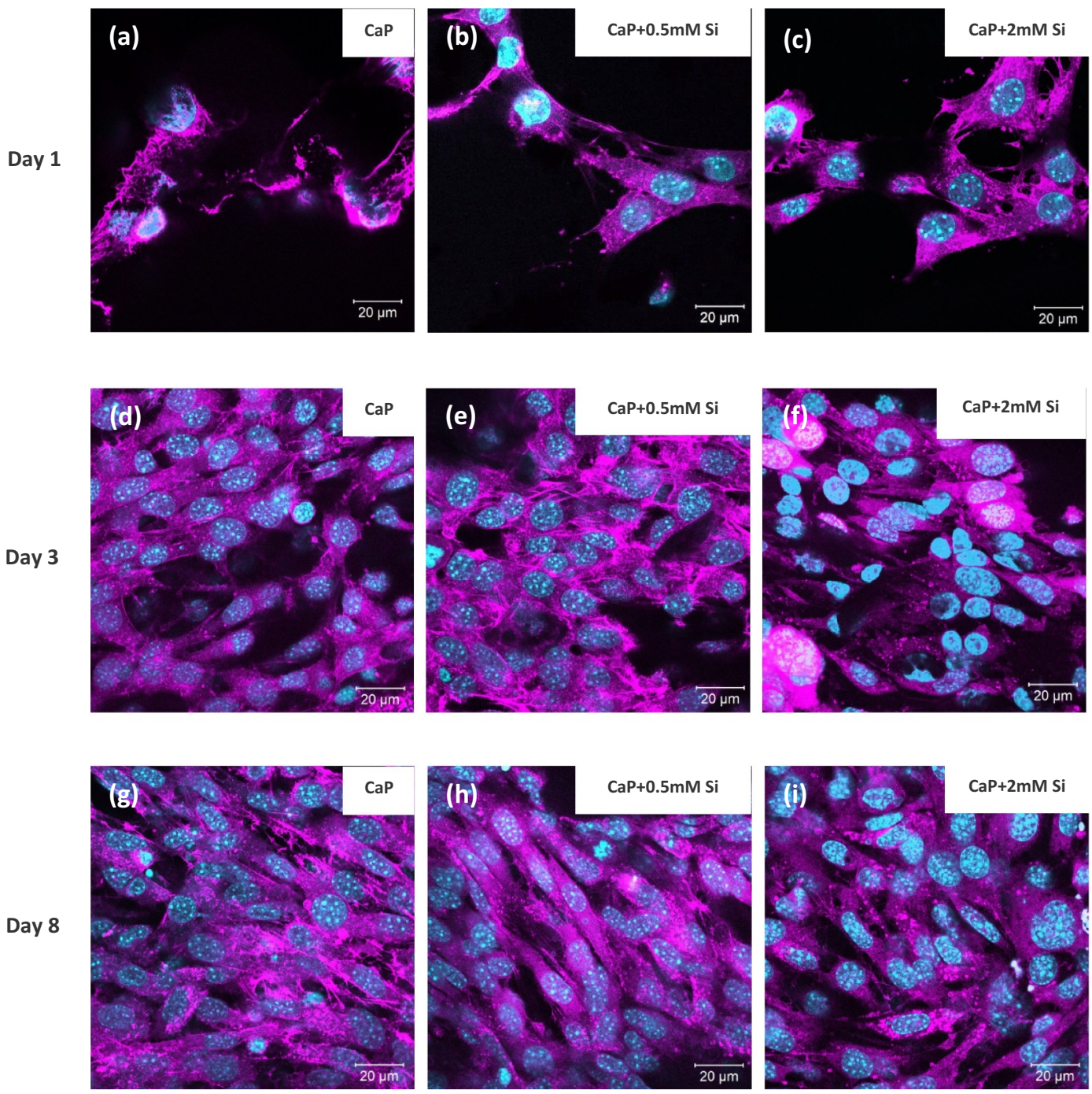

Fig. 7. Images of STRO- $1+$ A cells cultured on $\mathrm{CaP}(\mathrm{a}, \mathrm{d}, \mathrm{g}), \mathrm{CaP}+0.5 \mathrm{mM} \mathrm{Si}(\mathrm{b}, \mathrm{e}, \mathrm{h})$ or $\mathrm{CaP}+2 \mathrm{mM} \mathrm{Si}(\mathrm{c}, \mathrm{f}, \mathrm{i})$ coatings respectively for 1,3 and 8 days. Nucleus and actin cytoskeleton were stained in blue and magenta respectively. Scale bar: $20 \mu \mathrm{m}$. Data are representative of two different experiments performed in duplicate. (For interpretation of the references to colour in this figure legend, the reader is referred to the web version of this article.)

was the optimal formulation for coatings displaying the substrates' best physical-chemical properties such as roughness, thickness and compact structure comparable to the inorganic structure of the bone.

The STRO- $1^{+}$A human pre-osteoblast culture on supports revealed that the $\mathrm{CaP}+0.5 \mathrm{mM} \mathrm{Si}$ coating induced better cell viability according to the live/dead test. Cellular studies showed that the Si did not induce any cytotoxicity on STRO- $1^{+}$A cells. The biocompatibility of Si doped supports was confirmed by the study of cell morphology.

In this study an easy, fast, sterilization-resistant and inexpensive way to functionalize $316 \mathrm{~L}$ SS supports was developed. We propose an alternative and efficient method based onto $\mathrm{CaP}$ doped Si electrodeposition to functionalize metallic biomaterials useful for orthopedic and dental applications.

\section{Declaration of Competing Interest}

The authors declare that they have no known competing financial interests or personal relationships that could have appeared to influence the work reported in this paper.

\section{Acknowledgments}

Mrs. Hamdaoui acknowledges Campus Francefor her grant.

\section{References}

[1] M. Niinomi, M. Nakai, J. Hieda, Development of new metallic alloys for biomedical applications, Acta Biomater. 8 (11) (2012) 3888-3903.

[2] C. G, Bio-implants Market- Global Opportunity Analysis and Industry Forecast, (2014), pp. 2013-2020.

[3] A.M. Kumar, S. Nagarajan, S. Ramakrishna, P. Sudhagar, Y.S. Kang, H. Kim, Z.M. Gasem, N. Rajendran, Electrochemical and in vitro bioactivity of polypyrrole/ ceramic nanocomposite coatings on 316L SS bio-implants, Mater. Sci. Eng. C-Mater. Biol. Appl. 43 (2014) 76-85.

[4] Y.C. Su, C. Luo, Z.H. Zhang, H. Hermawan, D.H. Zhu, J.B. Huang, Y.H. Liang, G.Y. Li, L.Q. Ren, Bioinspired surface functionalization of metallic biomaterials, J Mech. Behav. Biomed. Mater. 77 (2018) 90-105.

[5] M. Navarro, A. Michiardi, O. Castaño, J.A. Planell, Biomaterials in orthopaedics, J. R. Soc. Interface 5 (27) (2008) 1137-1158.

[6] V.K. Balla, M. Das, S. Bose, G.D. Ram, I. Manna, Laser surface modification of 316 L stainless steel with bioactive hydroxyapatite, Mater. Sci. Eng. C Mater. Biol. Appl. 33 (8) (2013) 4594-4598.

[7] S. Sutha, K. Kavitha, G. Karunakaran, V. Rajendran, In-vitro bioactivity, biocorrosion and antibacterial activity of silicon integrated hydroxyapatite/chitosan composite coating on 316 L stainless steel implants, Mater. Sci. Eng. C Mater. Biol. Appl. 33 (7) (2013) 4046-4054.

[8] A. Bekmurzayeva, W.J. Duncanson, H.S. Azevedo, D. Kanayeva, Surface modification of stainless steel for biomedical applications: revisiting a century-old material, Mater. Sci. Eng. C-Mater. Biol. Appl. 93 (2018) 1073-1089.

[9] D. Xie, G.J. Wan, M.F. Maitz, H. Sun, N. Huang, Deformation and corrosion behaviors of Ti-O film deposited 316L stainless steel by plasma immersion ion implantation and deposition, Surf. Coat. Technol. 214 (2013) 117-123.

[10] L. Wang, X. Zhao, M.H. Ding, H. Zheng, H.S. Zhang, B. Zhang, X.Q. Li, G.Y. Wu, 
Surface modification of biomedical AISI 316L stainless steel with zirconium carbonitride coatings, Appl. Surf. Sci. 340 (2015) 113-119.

[11] S. Tavakoli, S. Nemati, M. Kharaziha, S. Akbari-Alavijeh, Embedding CuO nanoparticles in PDMS-SiO2 coating to improve antibacterial characteristic and corrosion resistance, Colloid Interface Sci. Commun. 28 (2019) 20-28.

[12] A. Latifi, M. Imani, M.T. Khorasani, M.D. Joupari, Electrochemical and chemical methods for improving surface characteristics of 316L stainless steel for biomedical applications, Surf. Coat. Technol. 221 (2013) 1-12.

[13] E. Salahinejad, M.J. Hadianfard, D.D. Macdonald, M. Mozafari, D. Vashaee, L. Tayebi, A new double-layer sol-gel coating to improve the corrosion resistance of a medical-grade stainless steel in a simulated body fluid, Mater. Lett. 97 (2013) $162-165$.

[14] L.L. Zhang, S.J. Liu, H.C. Han, Y. Zhou, S.C. Hu, C. He, Q.X. Yan, Studies on the formation process and anti-corrosion performance of polypyrrole film deposited on the surface of Q235 steel by an electrochemical method, Surf. Coat. Technol. 341 (2018) 95-102.

[15] N.C.T. Martins, T.M.E. Silva, M.F. Montemor, J.C.S. Fernandes, M.G.S. Ferreira, Electrodeposition and characterization of polypyrrole films on aluminium alloy 6061-T6, Electrochim. Acta 53 (14) (2008) 4754-4763.

[16] D. Gopi, S. Ramya, D. Rajeswari, L. Kavitha, Corrosion protection performance of porous strontium hydroxyapatite coating on polypyrrole coated 316L stainless steel, Colloids Surf. B-Biointerfaces 107 (2013) 130-136.

[17] D. Gopi, J. Indira, L. Kavitha, J.M.F. Ferreira, Hydroxyapatite coating on selectively passivated and sensitively polymer-protected surgical grade stainless steel, J. Appl. Electrochem. 43 (3) (2013) 331-345.

[18] M.B. Gonzalez, S.B. Saidman, Electrodeposition of polypyrrole on 316L stainless steel for corrosion prevention, Corros. Sci. 53 (1) (2011) 276-282.

[19] M. Eslami, G. Speranza, M. Fedel, N.E. Andersson, F. Deflorian, S. Omanovic, C. Zanella, Electropolymerization and possible corrosion protection effect of polypyrrole coatings on AA1050 (UNS A91050) in NaCl solutions, Corrosion 75 (7) (2019) 745-755.

[20] R. Balint, N.J. Cassidy, S.H. Cartmell, Conductive polymers: towards a smart biomaterial for tissue engineering, Acta Biomater. 10 (6) (2014) 2341-2353.

[21] X.L. Zhao, L.L. Jin, H.F. Shi, W.J. Tong, D. Gorin, Y. Kotelevtsev, Z.W. Mao, Recent advances of designing dynamic surfaces to regulate cell adhesion, Colloid Interface Sci. Commun. 35 (2020).

[22] X.Y. Cui, J.F. Hetke, J.A. Wiler, D.J. Anderson, D.C. Martin, Electrochemical deposition and characterization of conducting polymer polypyrrole/PSS on multichannel neural probes, Sensors Actuat. A-Phys. 93 (1) (2001) 8-18.

[23] R. Chakraborty, J.S. Manna, P. Saha, Development and relative comparison of polypyrrole-calcium phosphate composite coatings with differential concentration of chlorophyll functionalized polymer particle achieved through pulsed electro deposition, Surf. Coat. Technol. 363 (2019) 221-235.

[24] B. Maimaiti, N. Zhang, L. Yan, J. Luo, C. Xie, Y. Wang, C. Ma, T. Ye, Stable ZnOdoped hydroxyapatite nanocoating for anti-infection and osteogenic on titanium, Colloids Surf. B: Biointerfaces 186 (2019) 110731.

[25] R. Chakraborty, V.S. Seesala, J.S. Manna, P. Saha, S. Dhara, Synthesis, characterization and cytocompatibility assessment of hydroxyapatite-polypyrrole composite coating synthesized through pulsed reverse electrochemical deposition, Mater. Sci. Eng. C-Mater. Biol. Appl. 94 (2019) 597-607.

[26] R. Chakraborty, P. Saha, A comparative study on surface morphology and electrochemical behaviour of hydroxyapatite-calcium hydrogen phosphate composite coating synthesized in-situ through electro chemical process under various deposition conditions, Surf. Interfaces 12 (2018) 160-167.

[27] A. Robin, G. Silva, J.L. Rosa, Corrosion behavior of HA-316L SS biocomposites in aqueous solutions, Mater. Res.-Ibero-Am. J. Mater. 16 (6) (2013) 1254-1259.

[28] J. Jeong, J.H. Kim, J.H. Shim, N.S. Hwang, C.Y. Heo, Bioactive calcium phosphate materials and applications in bone regeneration, Biomater. Res. 23 (2019) 4.

[29] Y. Su, I. Cockerill, Y. Zheng, L. Tang, Y.X. Qin, D. Zhu, Biofunctionalization of metallic implants by calcium phosphate coatings, Bioact. Mater. 4 (2019) 196-206.

[30] K. Anselme, Osteoblast adhesion on biomaterials, Biomaterials 21 (7) (2000) $667-681$.

[31] R.A. Surmenev, M.A. Surmeneva, A.A. Ivanova, Significance of calcium phosphate coatings for the enhancement of new bone osteogenesis-a review, Acta Biomater. 10 (2) (2014) 557-579.

[32] B.W. Cunningham, N. Hu, C.M. Zorn, P.C. McAfee, Bioactive titanium calcium phosphate coating for disc arthroplasty: analysis of 58 vertebral end plates after 6to 12-month implantation, Spine J. 9 (10) (2009) 836-845.

[33] A.F. Khan, M. Saleem, A. Afzal, A. Ali, A. Khan, A.R. Khan, Bioactive behavior of silicon substituted calcium phosphate based bioceramics for bone regeneration, Mater. Sci. Eng. C Mater. Biol. Appl. 35 (2014) 245-252.

[34] H.M. da Silva, M. Mateescu, A. Ponche, C. Damia, E. Champion, G. Soares, K. Anselme, Surface transformation of silicon-doped hydroxyapatite immersed in culture medium under dynamic and static conditions, Colloids Surf. B-Biointerfaces 75 (1) (2010) 349-355.

[35] M. Qadir, Y.C. Li, C. Wen, Ion-substituted calcium phosphate coatings by physical vapor deposition magnetron sputtering for biomedical applications: a review, Acta Biomater. 89 (2019) 14-32.

[36] T. Gao, H.T. Aro, H. Ylanen, E. Vuorio, Silica-based bioactive glasses modulate expression of bone morphogenetic protein-2 mRNA in Saos-2 osteoblasts in vitro, Biomaterials 22 (12) (2001) 1475-1483.

[37] E. Boanini, M. Gazzano, A. Bigi, Ionic substitutions in calcium phosphates synthesized at low temperature, Acta Biomater. 6 (6) (2010) 1882-1894.
[38] C.A. Aboltins, V. Antoci, S. Bhattacharyya, M. Cross, P. Ducheyne, A.A. Freiberg, N. Hailer, P. Kay, C. Ketonis, M.R. Klement, N. Kose, M. Lee, P. Mitchell, S. Nandi, J.C. Palacio, K. Perry, H. Prieto, A. Shahi, R. Trebse, D. Turner, C.-T. Wu, H. Yazdi, Hip and knee section, prevention, prosthesis factors: proceedings of international consensus on orthopedic infections, J. Arthroplast. 34 (2S) (2019) S309-S320.

[39] S. Kim, J.O. Jeong, S. Lee, J.S. Park, H.J. Gwon, S.I. Jeong, J.G. Hardy, Y.M. Lim, J.Y. Lee, Effective gamma-ray sterilization and characterization of conductive polypyrrole biomaterials, Sci. Rep. 8 (2018).

[40] C.R. Harrell, V. Djonov, C. Fellabaum, V. Volarevic, Risks of using sterilization by gamma radiation: the other side of the coin, Int. J. Med. Sci. 15 (3) (2018) 274-279.

[41] I.R. Williams, M.B. Mayor, J.P. Collier, The impact of sterilization method on wear in knee arthroplasty, Clin. Orthop. Relat. Res. 356 (1998) 170-180.

[42] N. Ribeiro, G.C. Soares, V. Santos-Rosales, A. Concheiro, C. Alvarez-Lorenzo, C.A. Garcia-Gonzalez, A.L. Oliveira, A new era for sterilization based on supercritical CO2 technology, J. Biomed. Mater. Res. B-Appl. Biomater. 108 (2) (2020) $399-428$.

[43] S. Adler, M. Scherrer, F.D. Daschner, Costs of low-temperature plasma sterilization compared with other sterilization methods, J. Hosp. Infect. 40 (2) (1998) 125-134.

[44] C.C. Shih, Y.Y. Su, L.C. Chen, C.M. Shih, S.J. Lin, Degradation of 316L stainless steel sternal wire by steam sterilization, Acta Biomater. 6 (6) (2010) 2322-2328.

[45] T. Kokubo, H. Takadama, How useful is SBF in predicting in vivo bone bioactivity? Biomaterials 27 (15) (2006) 2907-2915.

[46] K.P. Ananth, A.J. Nathanael, S.P. Jose, T.H. Oh, D. Mangalaraj, A novel silica nanotube reinforced ionic incorporated hydroxyapatite composite coating on polypyrrole coated 316L SS for implant application, Mater. Sci. Eng. C-Mater. Biol. Appl. 59 (2016) 1110-1124.

[47] N. Aravindan, M.V. Sangaranarayanan, Influence of solvent composition on the anti-corrosion performance of copper-polypyrrole (cu-PPy) coated 304 stainless steel, Prog. Org. Coat. 95 (2016) 38-45.

[48] T. Mokabber, Q. Zhou, A.I. Vakis, P. van Rijn, Y.T. Pei, Mechanical and biological properties of electrodeposited calcium phosphate coatings, Mater. Sci. Eng. CMater. Biol. Appl. 100 (2019) 475-484.

[49] Y. Huang, M. Hao, X.F. Nian, H.X. Qiao, X.J. Zhang, X.Y. Zhang, G.Q. Song, J.C. Guo, X.F. Pang, H.L. Zhang, Strontium and copper co-substituted hydroxyapatite-based coatings with improved antibacterial activity and cytocompatibility fabricated by electrodeposition, Ceram. Int. 42 (10) (2016) 11876-11888.

[50] H.M. da Silva, M. Mateescu, C. Damia, E. Champion, G. Soares, K. Anselme, Importance of dynamic culture for evaluating osteoblast activity on dense siliconsubstituted hydroxyapatite, Colloids Surf. B: Biointerfaces 80 (2) (2010) 138-144.

[51] J. Wang, M. Wang, F. Chen, Y. Wei, X. Chen, Y. Zhou, X. Yang, X. Zhu, C. Tu, $\mathrm{X}$. Zhang, Nano-hydroxyapatite coating promotes porous calcium phosphate ceramic-induced osteogenesis via BMP/Smad Signaling pathway, Int. J. Nanomedicine 14 (2019) 7987-8000.

[52] F. Mangano, M. Raspanti, H. Maghaireh, C. Mangano, Scanning Electron microscope (SEM) evaluation of the Interface between a nanostructured calcium-incorporated dental implant surface and the human bone, Materials 10 (12) (2017).

[53] X. Li, B. Guo, Y. Xiao, T. Yuan, Y. Fan, X. Zhang, Influences of the steam sterilization on the properties of calcium phosphate porous bioceramics, J. Mater. Sci. Mater. Med. 27 (1) (2016) 5.

[54] R. Depprich, H. Zipprich, M. Ommerborn, E. Mahn, L. Lammers, J. Handschel, C. Naujoks, H.P. Wiesmann, N.R. Kübler, U. Meyer, Osseointegration of zirconia implants: an SEM observation of the bone-implant interface, Head Face Med 4 (2008) 25.

[55] F. Mastrangelo, R. Quaresima, L. Canullo, A. Scarano, L.L. Muzio, A. Piattelli, Effects of novel laser dental implant microtopography on human osteoblast proliferation and bone deposition, Int. J. Oral Maxillofac. Implants 35 (2) (2020) 320-329.

[56] X. Li, I. Zhitomirsky, Capacitive behaviour of polypyrrole films prepared on stainless steel substrates by electropolymerization, Mater. Lett. 76 (2012) 15-17.

[57] M. Palard, E. Champion, S. Foucaud, Synthesis of silicated hydroxyapatite Ca10(PO4)(6-x)(SiO4)(x)(OH)(2-x), J. Solid State Chem. 181 (8) (2008) 1950-1960.

[58] Y. Huang, S.G. Han, X.F. Pang, Q.Q. Ding, Y.J. Yan, Electrodeposition of porous hydroxyapatite/calcium silicate composite coating on titanium for biomedical applications, Appl. Surf. Sci. 271 (2013) 299-302.

[59] T. Jesionowski, L. Klapiszewski, G. Milczarek, Kraft lignin and silica as precursors of advanced composite materials and electroactive blends, J. Mater. Sci. 49 (3) (2014) 1376-1385.

[60] M. Lopez-Alvarez, E.L. Solla, P. Gonzalez, J. Serra, B. Leon, A.P. Marques, R.L. Reis, Silicon-hydroxyapatite bioactive coatings ( $\mathrm{Si}-\mathrm{HA}$ ) from diatomaceous earth and silica. Study of adhesion and proliferation of osteoblast-like cells, J. Mater. Sci.Mater. Med. 20 (5) (2009) 1131-1136.

[61] Y.L. Yang, K. Serpersu, W. He, S.R. Paital, N.B. Dahotre, Osteoblast interaction with laser cladded HA and SiO2-HA coatings on ti-6Al-4V, Mater. Sci. Eng. C-Mater. Biol. Appl. 31 (8) (2011) 1643-1652.

[62] L. Casarrubios, M.C. Matesanz, S. Sanchez-Salcedo, D. Arcos, M. Vallet-Regi, M.T. Portoles, Nanocrystallinity effects on osteoblast and osteoclast response to silicon substituted hydroxyapatite, J. Colloid Interface Sci. 482 (2016) 112-120.

[63] X. Qiu, P. Wan, L.L. Tan, X.M. Fan, K. Yang, Preliminary research on a novel bioactive silicon doped calcium phosphate coating on AZ31 magnesium alloy via electrodeposition, Mater. Sci. Eng. C-Mater. Biol. Appl. 36 (2014) 65-76.

[64] G. Lehmann, I. Cacciotti, P. Palmero, L. Montanaro, A. Bianco, L. Campagnolo, A. Camaioni, Differentiation of osteoblast and osteoclast precursors on pure and silicon-substituted synthesized hydroxyapatites, Biomed. Mater. 7 (5) (2012). 